\title{
COMPARATIVE ASSESSMENT OF MINERAL ELEMENTS AND HEAVY METALS ACCUMULATION IN VEGETABLE SPECIES
}

\author{
Nataša P. Nikolić, Milan K. Borišev, Slobodanka P. Pajević, Danijela D. Arsenov, Milan D. Župunski \\ University of Novi Sad, Faculty of Sciences, Department of Biology and Ecology, Trg Dositeja \\ Obradovića 2, 21000 Novi Sad, Republic of Serbia
}

\author{
${ }^{*}$ Corresponding author: \\ Telephone: +381214852652 \\ E-mail address: natasa.nikolic@dbe.uns.ac.rs
}

\begin{abstract}
The heavy metal (cadmium, lead, nickel, chromium) and mineral element (potassium, phosphorus, calcium, magnesium) levels in edible parts of tomato, potato, spinach, beetroot, parsley, parsnip, carrot, cauliflower, pepper and broccoli were determined by atomic absorption spectrophotometry. Six samples for each species originating from different localities were collected from green markets. The heavy metal concentrations ranged from $<0.01$ to $2.37,<0.01$ to $7.72,<0.01$ to 5.37 and $<0.01$ to $9.31 \mu \mathrm{g} / \mathrm{g}$ for cadmium, chromium, nickel and lead, respectively. The order of the macroelement concentrations in dry matter for all vegetable species was as follows: potassium > calcium > phosphorus > magnesium. The highest mean levels of the heavy metals, as well as of potassium, calcium and magnesium, were found in spinach. A large number of samples containing high levels of toxic heavy metals, especially of cadmium and lead, impose the necessity for strict regulative guidelines concerning individual vegetable crops production, harvest, handling and storing, in order to diminish possibility of contamination.
\end{abstract}

Key words: contaminants, food quality, heavy metals, mineral elements, vegetables

\section{INTRODUCTION}

Production of healthy and high-quality plants for human consumption should be considered as the prime goal of successful food production, beyond economic benefit. Vegetables and fruits are essential source of vitamins, mineral elements, fibres and also beneficial for human health (Radwan and Salama, 2006). Their everyday intake is highly recommended in the human diet, and their role in maintenance of health, and in prophylaxis and curing of numerous diseases is evident (D'Mello, 2003). Contents of both nutritive components important for human nutrition and other ineligible substances, such as heavy metals, determine the foodstuff quality and safety (Demirezen and Aksoy, 2006; Khoshgoftar- manesh et al., 2009; Mastilović et al., 2010).

Plants acquire heavy metals primarily from the soil, in concomitance with uptake and accumulation of elements essential for both plant metabolism and consumers organism, as well as from particle deposition on plant parts exposed to contaminated air (Zurera et al., 1997). Some of the heavy metals are trace elements (iron, copper, manganese, and zinc), commonly found in foodstuffs, fruits and vegetables, and are essential for a healthy life in small amounts. Also, plants easily uptake and accumulate toxic elements. Lead, cadmium, and mercury are nonessential heavy metals widely distributed throughout the 
environment due to soil erosion, intensive industrial and agricultural processes (Fowler, 1973; Svete et al., 2001). These elements are potent metabolic poisons to plants, animals, and humans, due to the poor potential of natural detoxification and their tendency to accumulate within the organism (Radwan and Salama, 2006). Higher doses of these metals may cause metabolic disorders, growth inhibition for most plants, thus reducing food quality (Majid et al., 2011). Therefore, the monitoring of heavy metals accumulation in plant foods has gained attention in recent years due to either their regulative role in metabolic processes or toxic effects on living organisms. The heavy metal contents in vegetables depend on the species and genotype, environmental conditions, manner of cultivation (field or glass house production), plant part, leaf arrangement (outer or inner), and methods of harvesting, processing and cooking (Quarterman, 1973; Stevanović et al., 2001; Jomová et al., 2004).

Growing demands for food production due to increase of human population encourage individual production of crop species at small farms. These products are available for consumers at green markets, but the process of their cultivation, harvest, transport and eventual storage conditions, as well as chemical composition analyses are far beyond any legislative control.

Considering the lack of information on mineral and heavy metal contents in vegetables originating from individual production on small farms, the aims of the present work were the following: a) to analyse the concentration of cadmium, nickel, lead and chromium in edible parts of vegetables, b) to identify good sources of essential mineral elements (potassium, phosphorus, magnesium and calcium) among analysed plants, c) to compare the heavy metals concentration with maximum permitted levels for food, d) to identify species efficient in heavy metal accumulation in edible parts of plants, e) to explore the relation between the origin of the vegetables and the heavy metal and mineral contents.

\section{MATERIAL AND METHODS}

Plant samples were collected from three green markets in the city of Novi Sad, during the period September-October 2011. Two samples of the same species from each market were collected, originating from different localities in the vicinity of Novi Sad. The samples included the most represented plants in human diet of the region: tomato (Lycopersicon esculentum Mill.), potato (Solanum tuberosum L.), spinach (Spinacia oleracea L.), beetroot (Beta vulgaris L.), parsley (Petroselinum crispum (Mill.) Fuss), parsnip (Pastinaca sativa L.), carrot (Daucus carota L.), cauliflower (Brassica oleracea L. var. botrytis L.), pepper (Capsicum annuum L.) and broccoli (Brassica oleracea L. var. sylvestris L.).

Only edible parts of the collected plants were subjected to further analysis. The samples were arranged on white paper and allowed to dry at room temperature for two days, following oven-drying at $80^{\circ} \mathrm{C} \mathrm{t}$ for $24 \mathrm{~h}$. Dry samples were milled and stored in clean and dry glass containers. Concentration of heavy metals and macroelements (potassium, calcium, phosphorus, magnesium) was determined by flame atomic absorption spectrophotometry (Varian, AAS240FS). The plant material was digested using closed vessel high pressure microwave digestion (Milestone D series Microwave Digestion System). The analysis of each sample was performed in three independent replicates.

The data were statistically processed using analysis of variance (ANOVA). Comparison of localities was estimated using Duncan's multiple range test, at a level of significance of $p<0.05$.

\section{RESULTS AND DISCUSSION}

The macroelement concentrations in selected vegetable species are given in Tables 1 and 2 . The values varied considerably between localities and plant species. Minerals are important and essential ingredients of diet required for optimal metabolic activities of the human body. The concentration of phosphorus ranged 
Table 1.

Phosphorus and potassium contents in edible portions of vegetable species (\% DM)

\begin{tabular}{|c|c|c|c|c|c|c|c|}
\hline Species & Locality & $\mathbf{P}$ & $\mathbf{K}$ & Species & Locality & $\mathbf{P}$ & K \\
\hline \multirow[t]{6}{*}{ Tomato } & I & $0.32 \pm 0.07 b$ & $3.57 \pm 0.05 a b$ & Beet root & I & $0.31 \pm 0.05 \mathrm{c}$ & $1.72 \pm 0.63 b$ \\
\hline & II & $0.26 \pm 0.03 b$ & $3.04 \pm 0.08 b c$ & & II & $0.18 \pm 0.04 d$ & $2.52 \pm 0.29 b$ \\
\hline & III & $0.19 \pm 0.01 b$ & $1.98 \pm 0.61 c$ & & III & $0.40 \pm 0.08 \mathrm{bc}$ & $2.56 \pm 0.38 b$ \\
\hline & IV & $0.55 \pm 0.08 \mathrm{a}$ & $4.43 \pm 0.27 a$ & & IV & $0.30 \pm 0.05 c$ & $2.60 \pm 0.36 b$ \\
\hline & V & $0.64 \pm 0.11 \mathrm{a}$ & $4.74 \pm 1.17 a$ & & V & $0.65 \pm 0.05 a$ & $4.08 \pm 0.06 a$ \\
\hline & $\mathrm{VI}$ & $0.69 \pm 0.07 \mathrm{a}$ & $4.60 \pm 0.32 a$ & & $\mathrm{VI}$ & $0.51 \pm 0.06 \mathrm{~b}$ & $1.97 \pm 0.63 b$ \\
\hline \multirow[t]{6}{*}{ Potato } & $\mathrm{I}$ & $0.32 \pm 0.03 \mathrm{ab}$ & $2.74 \pm 0.22 a$ & Spinach & I & $0.65 \pm 0.01 a$ & $4.33 \pm 0.60 \mathrm{bc}$ \\
\hline & II & $0.36 \pm 0.01 a$ & $2.19 \pm 0.07 b$ & & II & $0.60 \pm 0.08 a$ & $5.73 \pm 0.66 a$ \\
\hline & III & $0.27 \pm 0.02 b c$ & $2.75 \pm 0.08 a$ & & III & $0.35 \pm 0.04 b$ & $3.98 \pm 0.29 c$ \\
\hline & IV & $0.29 \pm 0.04 a b$ & $2.49 \pm 0.07 a b$ & & IV & $0.34 \pm 0.10 \mathrm{~b}$ & $5.33 \pm 0.88 a b$ \\
\hline & V & $0.21 \pm 0.07 \mathrm{c}$ & $2.45 \pm 0.64 \mathrm{ab}$ & & V & $0.24 \pm 0.04 b$ & $3.84 \pm 0.22 c$ \\
\hline & VI & $0.32 \pm 0.03 \mathrm{ab}$ & $2.21 \pm 0.14 a b$ & & VI & $0.67 \pm 0.06 a$ & $3.08 \pm 0.18 c$ \\
\hline \multirow[t]{6}{*}{ Cauliflower } & $\mathrm{I}$ & $0.69 \pm 0.02 a$ & $5.60 \pm 0.16 a$ & Carrot & $\mathrm{I}$ & $0.39 \pm 0.05 b c$ & $2.91 \pm 0.14 b$ \\
\hline & II & $0.55 \pm 0.10 \mathrm{a}$ & $3.89 \pm 0.15 c$ & & II & $0.43 \pm 0.09 b$ & $2.96 \pm 0.35 b$ \\
\hline & III & $0.65 \pm 0.01 a$ & $4.54 \pm 0.61 b$ & & III & $0.40 \pm 0.09 b c$ & $2.38 \pm 0.05 b c$ \\
\hline & IV & $0.56 \pm 0.13 a$ & $3.96 \pm 0.37 c$ & & IV & $0.71 \pm 0.00 \mathrm{a}$ & $4.34 \pm 0.68 a$ \\
\hline & V & $0.71 \pm 0.02 \mathrm{a}$ & $3.31 \pm 0.04 d$ & & V & $0.35 \pm 0.02 c$ & $2.18 \pm 0.15 c$ \\
\hline & $\mathrm{VI}$ & $0.35 \pm 0.06 \mathrm{~b}$ & $2.24 \pm 0.18 \mathrm{e}$ & & $\mathrm{VI}$ & $0.44 \pm 0.07 \mathrm{~b}$ & $2.23 \pm 0.01 \mathrm{c}$ \\
\hline \multirow[t]{6}{*}{ Parsley } & $\mathrm{I}$ & $0.44 \pm 0.01 \mathrm{ab}$ & $3.85 \pm 0.39 a$ & Broccoli & $\mathrm{I}$ & $0.49 \pm 0.03 c$ & $2.53 \pm 0.38 c$ \\
\hline & II & $0.25 \pm 0.07 d$ & $1.66 \pm 0.03 c$ & & II & $0.55 \pm 0.03 b c$ & $3.95 \pm 0.11 b$ \\
\hline & III & $0.26 \pm 0.07 \mathrm{~cd}$ & $1.71 \pm 0.01 \mathrm{c}$ & & III & $0.70 \pm 0.01 \mathrm{a}$ & $4.96 \pm 0.01 a$ \\
\hline & IV & $0.39 \pm 0.10 \mathrm{bc}$ & $2.16 \pm 0.01 b$ & & IV & $0.68 \pm 0.02 a$ & $4.13 \pm 0.16 b$ \\
\hline & V & $0.53 \pm 0.04 a$ & $2.49 \pm 0.14 b$ & & V & $0.66 \pm 0.02 a$ & $3.98 \pm 0.23 b$ \\
\hline & VI & $0.53 \pm 0.02 a$ & $2.12 \pm 0.04 b$ & & VI & $0.57 \pm 0.02 \mathrm{~b}$ & $2.98 \pm 0.23 \mathrm{c}$ \\
\hline \multirow[t]{6}{*}{ Parsnip } & I & $0.35 \pm 0.06 c$ & $2.09 \pm 0.46 b$ & Pepper & $\mathrm{I}$ & $0.31 \pm 0.02 d$ & $3.03 \pm 0.17 b$ \\
\hline & II & $0.40 \pm 0.02 c$ & $1.96 \pm 0.10 b$ & & II & $0.44 \pm 0.01 \mathrm{c}$ & $3.10 \pm 0.29 b$ \\
\hline & III & $0.36 \pm 0.04 \mathrm{c}$ & $1.86 \pm 0.03 b$ & & III & $0.59 \pm 0.03 b$ & $3.64 \pm 0.07 a$ \\
\hline & IV & $0.55 \pm 0.02 b$ & $1.91 \pm 0.20 \mathrm{~b}$ & & IV & $0.19 \pm 0.03 \mathrm{e}$ & $2.26 \pm 0.18 c$ \\
\hline & V & $0.77 \pm 0.00 \mathrm{a}$ & $4.59 \pm 0.17 a$ & & V & $0.54 \pm 0.05 b$ & $2.80 \pm 0.09 b$ \\
\hline & VI & $0.21 \pm 0.01 d$ & $1.76 \pm 0.55 b$ & & VI & $0.75 \pm 0.07 a$ & $2.96 \pm 0.09 b$ \\
\hline
\end{tabular}

Data presented as mean values \pm SD. Means for each species within the column followed by different letters are significantly different $(p<0.05)$

from $0.18 \%$ (beet root, locality II) to $0.77 \%$ (parsnip, locality V). According to average phosphorus concentration, cauliflower and broccoli are good sources of this mineral in the human diet. The majority of phosphorus found in the human body is bound up with calcium in the bones as calcium phosphate, and the remainder is distributed as inorganic phosphate and in all cells as ATP, as well as in the genetic materials of DNA and RNA (Haas and Levin, 2006). It is involved in most biochemical reactions, energy production and exchange. Phosphorus and calcium combine in equal amounts to form the calcium phosphate in bones, so the ideal ratio of calcium to phosphorus in the diet is 1:1 (Haas and Levin, 2006). Of all vegetable species studied in the present work, the closest to ideal calcium/phosphorus ratio was found in parsnip (1.15) and pepper (1.17).
Calcium is the most abundant mineral in the human body, serving important functions in the formation of bones and teeth, regular behaviour of heart muscles, nerves and the blood clotting processes. Magnesium is important for proper muscle contraction, blood clotting, the regulation of blood pressure and lung function (Menchaca, 2009). It is also essential part of many enzymes responsible for transfer of energy (Danilcenko et al., 2011). In the vegetable species analysed, calcium ranged from $0.23 \%$ (parsnip, locality I) to $2.1 \%$ (beet root, locality $\mathrm{VI}$ ), and magnesium from $0.07 \%$ (potato, locality $\mathrm{VI}$ ) to $0.86 \%$ (beet root, locality II). The dietary calcium/magnesium ratio is responsible for the frequency of heart diseases (Kikunaga et al., 1999), and the recommended ratio that lowers this risk is $2: 1$. In vegetable species surveyed in the present work, 
Table 2.

Calcium and magnesium contents in edible portions of vegetable species (\% DM)

\begin{tabular}{|c|c|c|c|c|c|c|c|}
\hline Species & Locality & $\mathrm{Ca}$ & $\mathrm{Mg}$ & Species & Locality & $\mathrm{Ca}$ & $\mathbf{M g}$ \\
\hline \multirow[t]{6}{*}{ Tomato } & I & $0.41 \pm 0.06 c$ & $0.15 \pm 0.02 b$ & Beet root & I & $1.38 \pm 0.29 b$ & $0.18 \pm 0.01 \mathrm{ab}$ \\
\hline & II & $0.53 \pm 0.00 \mathrm{bc}$ & $0.52 \pm 0.12 a$ & & II & $0.90 \pm 0.11 \mathrm{bcd}$ & $0.27 \pm 0.10 a b$ \\
\hline & III & $0.78 \pm 0.16 b c$ & $0.21 \pm 0.04 b$ & & III & $1.17 \pm 0.53 b c$ & $0.36 \pm 0.10 a$ \\
\hline & IV & $0.91 \pm 0.39 b$ & $0.24 \pm 0.1 b$ & & IV & $0.57 \pm 0.26 \mathrm{~cd}$ & $0.19 \pm 0.05 a b$ \\
\hline & V & $1.61 \pm 0.31 a$ & $0.23 \pm 0.09 b$ & & V & $0.36 \pm 0.08 d$ & $0.14 \pm 0.01 b$ \\
\hline & VI & $0.41 \pm 0.06 c$ & $0.16 \pm 0.00 b$ & & VI & $2.10 \pm 0.34 \mathrm{a}$ & $0.35 \pm 0.01 \mathrm{a}$ \\
\hline \multirow[t]{6}{*}{ Potato } & I & $0.39 \pm 0.06 d$ & $0.09 \pm 0.01 \mathrm{c}$ & Spinach & 1 & $1.30 \pm 0.65 a b$ & $0.21 \pm 0.06 \mathrm{e}$ \\
\hline & II & $0.50 \pm 0.06 \mathrm{~cd}$ & $0.15 \pm 0.01 b c$ & & II & $1.74 \pm 0.02 a$ & $0.86 \pm 0.01 a$ \\
\hline & III & $0.90 \pm 0.43 b c$ & $0.24 \pm 0.09 a b$ & & III & $1.90 \pm 0.17 a$ & $0.43 \pm 0.02 \mathrm{c}$ \\
\hline & IV & $1.75 \pm 0.38 a$ & $0.09 \pm 0.01 \mathrm{c}$ & & IV & $1.32 \pm 0.17 a b$ & $0.31 \pm 0.00 d$ \\
\hline & V & $1.32 \pm 0.17 \mathrm{ab}$ & $0.27 \pm 0.1 \mathrm{a}$ & & V & $0.67 \pm 0.13 b$ & $0.17 \pm 0.00 \mathrm{e}$ \\
\hline & $\mathrm{VI}$ & $0.18 \pm 0.05 d$ & $0.07 \pm 0.01 \mathrm{c}$ & & VI & $1.84 \pm 0.32 a$ & $0.68 \pm 0.03 b$ \\
\hline \multirow[t]{6}{*}{ Cauliflower } & $\mathrm{I}$ & $0.64 \pm 0.05 \mathrm{c}$ & $0.18 \pm 0.00 \mathrm{~b}$ & Carrot & $\mathrm{I}$ & $0.93 \pm 0.42 \mathrm{~b}$ & $0.19 \pm 0.04 b$ \\
\hline & II & $0.62 \pm 0.01 \mathrm{c}$ & $0.16 \pm 0.01 b$ & & II & $1.96 \pm 0.35 a$ & $0.15 \pm 0.01 b$ \\
\hline & III & $1.20 \pm 0.29 b$ & $0.25 \pm 0.02 a b$ & & III & $0.75 \pm 0.09 \mathrm{bc}$ & $0.20 \pm 0.03 b$ \\
\hline & IV & $1.96 \pm 0.34 a$ & $0.30 \pm 0.12 a$ & & IV & $0.66 \pm 0.07 \mathrm{bc}$ & $0.18 \pm 0.02 b$ \\
\hline & V & $0.51 \pm 0.02 c$ & $0.17 \pm 0.00 \mathrm{~b}$ & & V & $0.40 \pm 0.05 \mathrm{c}$ & $0.75 \pm 0.49 a$ \\
\hline & VI & $1.21 \pm 0.22 b$ & $0.16 \pm 0.01 \mathrm{~b}$ & & VI & $0.40 \pm 0.05 c$ & $0.12 \pm 0.01 \mathrm{~b}$ \\
\hline \multirow{6}{*}{ Parsley } & $\mathrm{I}$ & $0.68 \pm 0.32 b$ & $0.25 \pm 0.08 \mathrm{ab}$ & Broccoli & 1 & $0.49 \pm 0.16 c$ & $0.13 \pm 0.02 a$ \\
\hline & II & $0.97 \pm 0.22 b$ & $0.23 \pm 0.00 \mathrm{bc}$ & & II & $0.65 \pm 0.03 c$ & $0.15 \pm 0.02 a$ \\
\hline & III & $0.66 \pm 0.09 b$ & $0.30 \pm 0.02 a$ & & III & $0.96 \pm 0.16 \mathrm{ab}$ & $0.20 \pm 0.04 a$ \\
\hline & IV & $0.89 \pm 0.03 b$ & $0.31 \pm 0.01 a$ & & IV & $1.15 \pm 0.04 \mathrm{a}$ & $0.23 \pm 0.01 a$ \\
\hline & V & $1.90 \pm 0.54 a$ & $0.17 \pm 0.01 \mathrm{c}$ & & V & $0.92 \pm 0.20 b$ & $0.19 \pm 0.02 a$ \\
\hline & VI & $0.40 \pm 0.07 \mathrm{~b}$ & $0.21 \pm 0.00 \mathrm{bc}$ & & VI & $0.58 \pm 0.04 c$ & $0.10 \pm 0.01 \mathrm{a}$ \\
\hline \multirow[t]{6}{*}{ Parsnip } & $\mathrm{I}$ & $0.23 \pm 0.01 \mathrm{c}$ & $0.12 \pm 0.00 \mathrm{~cd}$ & Pepper & 1 & $0.44 \pm 0.09 \mathrm{~b}$ & $0.16 \pm 0.00 \mathrm{ab}$ \\
\hline & II & $0.34 \pm 0.01 \mathrm{c}$ & $0.16 \pm 0.01 \mathrm{c}$ & & II & $0.40 \pm 0.01 \mathrm{~b}$ & $0.13 \pm 0.00 \mathrm{~b}$ \\
\hline & III & $0.66 \pm 0.23 b$ & $0.27 \pm 0.05 b$ & & III & $0.81 \pm 0.05 a$ & $0.21 \pm 0.02 a$ \\
\hline & IV & $0.61 \pm 0.08 b$ & $0.24 \pm 0.02 b$ & & IV & $0.77 \pm 0.58 a$ & $0.17 \pm 0.03 \mathrm{ab}$ \\
\hline & V & $0.98 \pm 0.02 a$ & $0.48 \pm 0.05 a$ & & V & $0.33 \pm 0.08 \mathrm{~b}$ & $0.12 \pm 0.01 b$ \\
\hline & VI & $0.27 \pm 0.04 c$ & $0.09 \pm 0.02 d$ & & VI & $0.46 \pm 0.04 b$ & $0.15 \pm 0.02 \mathrm{ab}$ \\
\hline
\end{tabular}

Data presented as mean values \pm SD. Means for each species within the column followed by different letters are significantly different $(p<0.05)$

this ratio was $3.08,5.6,3.15,5.10,4.65$, $4.32,3.43,2.22,3.83$ and 3.32 , for tomato, potato, carrot, cauliflower, broccoli, beet root, pepper, parsnip, parsley and spinach, respectively. The favourable ratio was recorded only in parsnip. Increased values obtained in majority of vegetable samples suggest increased calcium intake in humans, which disadvantages magnesium absorption in human body (Nicar and Pak, 1982). Of the minerals surveyed in this work, the vegetable species contained potassium in highest amounts. This element is needed to regulate water balance, levels of acidity and electrolyte balance, as well as blood pressure. It is also involved in both electrical and cellular functions in human body. Food processing prior to consumption removes potassium, therefore decreases potassium intake; the population would benefit from an increase in potassium intake by more fresh fruit and vegetables (He and MacGregor, 2001). According to the analyses of vegetables in the present work, spinach, cauliflower, broccoli and tomato are good sources of this mineral, with concentrations of about $4 \%$. The highest concentrations of potassium, calcium and magnesium were recorded for spinach leaves. The relationship between concentrations of selected macroelements in dry matter for all vegetable species was as follows: potassium > calcium > phosphorus > magnesium. Average potassium values of other species fall within the range between 2.00 and $4.00 \%$, except for spinach containing $4.38 \%$ of potassium.

Lead and cadmium are among the most abundant heavy metals and are particularly toxic (Radwan and Salama, 2006). Significant variability of cadmium concen- 
Table 3.

Cadmium and lead contents in edible portions of vegetable species $(\mu \mathrm{g} / \mathrm{g} \mathrm{DM})$

\begin{tabular}{|c|c|c|c|c|c|c|c|}
\hline Species & Locality & Cd & $\mathbf{P b}$ & Species & Locality & Cd & $\mathbf{P b}$ \\
\hline \multirow[t]{6}{*}{ Tomato } & 1 & $0.12 \pm 0.02 c$ & $9.31 \pm 0.25 a$ & Beet root & 1 & $<0.01 \mathrm{~b}$ & $<0.01 \mathrm{~b}$ \\
\hline & II & $0.02 \pm 0.01 \mathrm{c}$ & $0.06 \pm 0.01 \mathrm{e}$ & & II & $0.03 \pm 0.01 b$ & $<0.01 b$ \\
\hline & III & $0.03 \pm 0.01 \mathrm{c}$ & $0.27 \pm 0.02 \mathrm{e}$ & & III & $0.02 \pm 0.01 \mathrm{~b}$ & $2.03 \pm 0.77 a$ \\
\hline & IV & $0.14 \pm 0.03 c$ & $6.40 \pm 1.66 b$ & & IV & $<0.01 b$ & $0.09 \pm 0.02 b$ \\
\hline & V & $1.17 \pm 0.22 a$ & $1.85 \pm 0.08 d$ & & V & $0.09 \pm 0.02 a$ & $0.11 \pm 0.03 \mathrm{~b}$ \\
\hline & VI & $0.81 \pm 0.22 b$ & $3.23 \pm 0.85 c$ & & $\mathrm{VI}$ & $0.02 \pm 0.01 b$ & $0.15 \pm 0.05 b$ \\
\hline \multirow[t]{6}{*}{ Potato } & I & $0.06 \pm 0.01 a$ & $1.96 \pm 0.55 a$ & Spinach & $\mathrm{I}$ & $1.34 \pm 0.52 a$ & $2.00 \pm 0.21 \mathrm{c}$ \\
\hline & II & $<0.01 b$ & $<0.01 \mathrm{c}$ & & II & $1.35 \pm 0.24 \mathrm{a}$ & $8.32 \pm 0.32 a$ \\
\hline & III & $0.05 \pm 0.01 a$ & $0.07 \pm 0.00 \mathrm{~b}$ & & III & $0.89 \pm 0.14 a$ & $9.07 \pm 0.32 a$ \\
\hline & IV & $<0.01 b$ & $1.80 \pm 0.46 a$ & & IV & $0.91 \pm 0.12 a$ & $8.83 \pm 0.79 a$ \\
\hline & V & $0.05 \pm 0.01 a$ & $0.06 \pm 0.01 b$ & & V & $0.01 \pm 0.00 b$ & $0.09 \pm 0.03 d$ \\
\hline & $\mathrm{VI}$ & $<0.01 b$ & $<0.01 c$ & & $\mathrm{VI}$ & $0.85 \pm 0.10 a$ & $6.56 \pm 1.05 d$ \\
\hline \multirow[t]{6}{*}{ Cauliflower } & $\mathrm{I}$ & $0.25 \pm 0.12 a$ & $5.67 \pm 1.25 a$ & Carrot & $\mathrm{I}$ & $0.14 \pm 0.02 \mathrm{~cd}$ & $3.83 \pm 0.86 a$ \\
\hline & II & $0.12 \pm 0.07 \mathrm{~b}$ & $1.59 \pm 0.15 c$ & & II & $0.35 \pm 0.13 b$ & $3.60 \pm 0.59 a$ \\
\hline & III & $0.09 \pm 0.03 b$ & $<0.01 d$ & & III & $0.01 \pm 0.00 b$ & $3.61 \pm 0.70 a$ \\
\hline & IV & $0.05 \pm 0.01 b$ & $3.41 \pm 1.15 b$ & & IV & $0.20 \pm 0.05 b c$ & $1.33 \pm 0.19 b$ \\
\hline & V & $0.11 \pm 0.07 \mathrm{~b}$ & $0.04 \pm 0.01 d$ & & V & $0.71 \pm 0.13 a$ & $1.78 \pm 0.28 b$ \\
\hline & VI & $<0.01 b$ & $0.08 \pm 0.02 d$ & & $\mathrm{VI}$ & $0.11 \pm 0.04 \mathrm{~cd}$ & $1.00 \pm 0.32 b$ \\
\hline \multirow[t]{6}{*}{ Parsley } & $\mathrm{I}$ & $0.04 \pm 0.01 b$ & $1.20 \pm 0.20 c$ & Broccoli & $\mathrm{I}$ & $2.37 \pm 0.16 a$ & $2.84 \pm 0.40 c$ \\
\hline & II & $0.10 \pm 0.02 b$ & $4.42 \pm 1.09 b$ & & II & $0.03 \pm 0.01 \mathrm{c}$ & $0.21 \pm 0.03 e$ \\
\hline & III & $0.02 \pm 0.05 b$ & $0.02 \pm 0.01 \mathrm{c}$ & & III & $0.08 \pm 0.03 c$ & $6.69 \pm 0.08 a$ \\
\hline & IV & $0.09 \pm 0.02 b$ & $0.12 \pm 0.03 c$ & & IV & $0.02 \pm 0.01 \mathrm{c}$ & $0.01 \pm 0.00 \mathrm{e}$ \\
\hline & V & $0.05 \pm 0.02 b$ & $3.89 \pm 0.18 b$ & & V & $0.30 \pm 0.02 b$ & $6.13 \pm 0.06 b$ \\
\hline & VI & $0.27 \pm 0.21 a$ & $6.00 \pm 0.77 a$ & & VI & $0.02 \pm 0.01 \mathrm{c}$ & $1.65 \pm 0.49 d$ \\
\hline \multirow[t]{6}{*}{ Parsnip } & I & $0.06 \pm 0.01 b$ & $0.02 \pm 0.01 \mathrm{c}$ & Pepper & 1 & $0.12 \pm 0.02 \mathrm{bc}$ & $3.72 \pm 0.65 b$ \\
\hline & II & $<0.01 b$ & $0.12 \pm 0.03 c$ & & II & $0.96 \pm 0.52 a$ & $2.27 \pm 0.27 c$ \\
\hline & III & $0.02 \pm 0.01 b$ & $0.23 \pm 0.09 c$ & & III & $0.74 \pm 0.13 \mathrm{ab}$ & $8.30 \pm 0.09 a$ \\
\hline & IV & $0.05 \pm 0.02 b$ & $2.70 \pm 1.08 b$ & & IV & $0.02 \pm 0.01 \mathrm{c}$ & $1.17 \pm 0.23 d$ \\
\hline & V & $1.09 \pm 0.27 a$ & $6.29 \pm 0.95 a$ & & V & $0.14 \pm 0.04 b c$ & $2.13 \pm 0.26 \mathrm{~cd}$ \\
\hline & VI & $0.02 \pm 0.01 b$ & $0.19 \pm 0.05 c$ & & $\mathrm{VI}$ & $0.20 \pm 0.05 b c$ & $1.98 \pm 0.83 \mathrm{~cd}$ \\
\hline
\end{tabular}

Data presented as mean values \pm SD. Means for each species within the column followed by different letters are significantly different $(p<0.05)$

tration within the same species was evident in relation to the localities (Table 3). Cadmium concentrations ranged from $<0.01$ (parsnip, beet root) to $2.37 \mu \mathrm{g} / \mathrm{g}$ (broccoli) in dry matter (DM). The range of Cd concentration in vegetables found in the current survey is in agreement with the results of De Pieri et al. (1997), who analysed cadmium and lead concentration of edible and non-edible parts of various vegetable plants. The authors found higher levels of cadmium and lead in non-edible parts, e.g., leaves of cauliflower, cabbage, turnip, carrot and corn, while in edible parts of vegetables cadmium concentration varied from 0.03 to $1.74 \mu \mathrm{g} / \mathrm{g}$ DM. According to the means obtained for each species in the present work, the highest accumulation of cadmium was observed in spinach, and the lowest in beet root and potato. Furthermore, parsley, spinach, cauliflower, carrot, tomato and potato con- tained more cadmium than samples from the Greek market (Karavoltsos et al., 2002).

Lead concentrations tended to be less uniform between localities and vegetable species than those of cadmium (Table 3 ). The values obtained in this survey ranged from $<0.01 \mu \mathrm{g} / \mathrm{g}$ (cauliflower, potato, beet root) to $9.31 \mu \mathrm{g} / \mathrm{g}$ (tomato). The results are comparable with those reported by Demirezen and Aksoy (2006), who found $\mathrm{Pb}$ concentration in eleven vegetable species ranging from 3 to $10.7 \mu \mathrm{g} / \mathrm{g}$. However, our findings are not in line with De Pieri et al. (1997), who reported relatively consistent and lower lead concentrations of edible portions of vegetables, falling between 0.03 and $0.16 \mu \mathrm{g} / \mathrm{g} \mathrm{DM}$. The elevated $\mathrm{Pb}$ concentrations may occur also in vegetables from protected cultivations, such as greenhouse, as a result of application of 
Table 4.

Chromium and nickel contents in edible portions of vegetable species ( $\mu \mathrm{g} / \mathrm{g} D \mathrm{DM})$

\begin{tabular}{|c|c|c|c|c|c|c|c|}
\hline Species & Locality & $\mathrm{Cr}$ & $\mathbf{N i}$ & Species & Locality & $\mathrm{Cr}$ & $\mathrm{Ni}$ \\
\hline \multirow[t]{6}{*}{ Tomato } & 1 & $1.64 \pm 0.04 b$ & $2.86 \pm 1.32 \mathrm{~b}$ & Beet root & I & $1.17 \pm 0.03 b c$ & $0.02 \pm 0.00 \mathrm{~b}$ \\
\hline & II & $1.06 \pm 0.04 c$ & $0.07 \pm 0.03 c$ & & II & $0.62 \pm 0.29 c$ & $0.03 \pm 0.01 b$ \\
\hline & III & $0.02 \pm 0.01 d$ & $0.04 \pm 0.02 c$ & & III & $1.38 \pm 0.44 b$ & $0.08 \pm 0.03 b$ \\
\hline & IV & $1.76 \pm 0.31 \mathrm{ab}$ & $1.68 \pm 0.40 \mathrm{~b}$ & & IV & $1.36 \pm 0.02 b$ & $0.06 \pm 0.01 b$ \\
\hline & V & $1.70 \pm 0.23 a b$ & $1.68 \pm 0.26 b$ & & V & $1.18 \pm 0.14 b c$ & $0.08 \pm 0.02 b$ \\
\hline & $\mathrm{VI}$ & $2.00 \pm 0.01 \mathrm{a}$ & $4.53 \pm 0.51 a$ & & VI & $1.96 \pm 0.28 a$ & $0.17 \pm 0.3 a$ \\
\hline \multirow[t]{6}{*}{ Potato } & 1 & $1.33 \pm 0.21 b$ & $0.97 \pm 0.22 b$ & Spinach & I & $1.58 \pm 0.27 c$ & $2.71 \pm 0.76 c$ \\
\hline & II & $<0.01 c$ & $<0.01 \mathrm{c}$ & & II & $7.13 \pm 0.21 a$ & $5.37 \pm 1.92 \mathrm{a}$ \\
\hline & III & $2.22 \pm 0.04 a b$ & $0.05 \pm 0.01 \mathrm{c}$ & & III & $1.25 \pm 0.14 \mathrm{c}$ & $3.82 \pm 0.07 \mathrm{bc}$ \\
\hline & IV & $2.54 \pm 0.93 a$ & $1.16 \pm 0.20 \mathrm{~b}$ & & IV & $2.81 \pm 0.46 \mathrm{~b}$ & $4.47 \pm 0.09 a b$ \\
\hline & V & $1.19 \pm 0.30 b$ & $0.38 \pm 0.05 c$ & & V & $1.55 \pm 0.52 \mathrm{c}$ & $0.01 \pm 0.00 d$ \\
\hline & $\mathrm{VI}$ & $1.52 \pm 0.55 a b$ & $2.56 \pm 0.30 \mathrm{a}$ & & $\mathrm{VI}$ & $7.72 \pm 0.93 a$ & $3.71 \pm 0.05 b c$ \\
\hline \multirow[t]{6}{*}{ Cauliflower } & $\mathrm{I}$ & $2.69 \pm 0.49 a$ & $2.63 \pm 0.05 a$ & Carrot & $\mathrm{I}$ & $2.13 \pm 0.65 a$ & $1.59 \pm 0.02 b$ \\
\hline & II & $1.08 \pm 0.14 b$ & $0.51 \pm 0.22 b c$ & & II & $1.30 \pm 0.08 \mathrm{~b}$ & $2.67 \pm 0.01 a$ \\
\hline & III & $0.07 \pm 0.01 \mathrm{c}$ & $0.03 \pm 0.01 \mathrm{c}$ & & III & $0.35 \pm 0.13 c$ & $0.24 \pm 0.03 d$ \\
\hline & IV & $0.43 \pm 0.05 c$ & $0.33 \pm 0.01 b c$ & & IV & $0.37 \pm 0.06 c$ & $0.94 \pm 0.41 \mathrm{c}$ \\
\hline & V & $1.48 \pm 0.39 b$ & $0.73 \pm 0.59 \mathrm{~b}$ & & V & $0.56 \pm 0.11 \mathrm{c}$ & $1.29 \pm 0.12 \mathrm{bc}$ \\
\hline & $\mathrm{VI}$ & $1.11 \pm 0.04 \mathrm{~b}$ & $0.08 \pm 0.02 c$ & & $\mathrm{VI}$ & $1.45 \pm 0.35 a$ & $1.41 \pm 0.21 b$ \\
\hline \multirow[t]{6}{*}{ Parsley } & $\mathrm{I}$ & $1.81 \pm 0.72 \mathrm{ab}$ & $2.36 \pm 0.01 a$ & Broccoli & $\mathrm{I}$ & $1.48 \pm 0.06 b$ & $1.47 \pm 0.15 c$ \\
\hline & II & $1.62 \pm 0.74 a b$ & $2.09 \pm 0.12 b$ & & II & $0.02 \pm 0.00 c$ & $2.77 \pm 0.07 a$ \\
\hline & III & $0.32 \pm 0.15 c$ & $0.81 \pm 0.09 c$ & & III & $1.68 \pm 0.33 b$ & $0.28 \pm 0.09 \mathrm{e}$ \\
\hline & IV & $0.93 \pm 0.35 b c$ & $0.61 \pm 0.02 c$ & & IV & $0.11 \pm 0.04 \mathrm{c}$ & $2.31 \pm 0.01 b$ \\
\hline & V & $1.27 \pm 0.08 \mathrm{abc}$ & $2.32 \pm 0.01 a$ & & V & $2.61 \pm 0.18 a$ & $2.41 \pm 0.20 b$ \\
\hline & VI & $2.25 \pm 0.52 a$ & $2.20 \pm 0.17 \mathrm{ab}$ & & VI & $1.34 \pm 0.28 b$ & $1.21 \pm 0.06 b$ \\
\hline \multirow[t]{6}{*}{ Parsnip } & I & $0.74 \pm 0.03 c$ & $<0.01 \mathrm{c}$ & Pepper & 1 & $2.06 \pm 0.74 a$ & $2.15 \pm 0.23 a$ \\
\hline & II & $1.13 \pm 0.32 c$ & $1.34 \pm 0.31 b$ & & II & $1.04 \pm 0.01 \mathrm{c}$ & $1.48 \pm 0.20 b$ \\
\hline & III & $2.17 \pm 0.44 b$ & $1.07 \pm 0.08 b$ & & III & $2.13 \pm 0.52 a$ & $0.18 \pm 0.07 c$ \\
\hline & IV & $1.45 \pm 0.12 b c$ & $1.45 \pm 0.03 b$ & & IV & $<0.01 d$ & $<0.01 \mathrm{c}$ \\
\hline & V & $4.52 \pm 0.29 a$ & $3.26 \pm 0.31 a$ & & V & $1.34 \pm 0.29 b c$ & $2.09 \pm 0.30 a$ \\
\hline & VI & $1.94 \pm 0.32 b$ & $1.41 \pm 0.15 b$ & & $\mathrm{VI}$ & $1.84 \pm 0.32 \mathrm{ab}$ & $1.48 \pm 0.22 b$ \\
\hline
\end{tabular}

Data presented as mean values \pm SD. Means for each species within the column followed by different letters are significantly different $(p<0.05)$

Pb-enriched manure, chemical fertilizers and pesticides (Khoshgoftarmanesh et al., 2009).

Chromium is essential mineral important for carbohydrate metabolism in humans and animals (Parveen et al., 2003). The concentration of chromium in analysed vegetable species varied from 0.01 to 7.30 $\mu \mathrm{g} / \mathrm{g}$ (Table 4). Significant differences were recorded in chromium concentration between localities of origin in all sampled species. Average values obtained for each species, taking into account all six localities; fell between 1.00 and $2.00 \mu \mathrm{g} / \mathrm{g}$, except for spinach with $3.67 \mu \mathrm{g} / \mathrm{g}$ of chromium. Beside chromium, spinach contained the highest average amounts of cadmium, nickel and lead as well (0.89, 3.35 and $5.81 \mu \mathrm{g} / \mathrm{g}$, respectively).

Nickel is a nutritionally essential trace metal for several animal species, micro- organisms and plants. Therefore, either deficiency or toxicity symptoms can occur when, too little or too much $\mathrm{Ni}$ is taken up, respectively (Cempel and Nikel, 2006). Essentiality of nickel is considered possible for human organism due to its role as a cofactor or structural component in an enzyme (Nielsen, 2003). Most nickel in the human body originates from drinking water and food, however, the gastrointestinal route is of lesser importance, due to its limited intestinal absorption (Cempel and Nikel, 2006). The nickel concentrations in selected vegetable samples were in the range from $<0.01 \mu \mathrm{g} / \mathrm{g}$ (potato, parsnip, pepper) to $5.37 \mu \mathrm{g} / \mathrm{g}$ (spinach) (Table 4). Nickel levels in foodstuffs generally range from less than 0.1 to $0.5 \mu \mathrm{g} / \mathrm{g}$ (Cempel and Nikel, 2006). Range of Ni concentrations obtained in the present work was lower than that reported for vegetables grown in 
either urban or rural areas in Turkey (Demirezen and Aksoy, 2006).

Accumulation of heavy metals in plants may be the consequence of irrigation with contaminated water, the addition of fertilizers and metal-based pesticides, Industrial emissions, transportation, harvesting process, activities during storage and/or sale (Radwan and Sharma, 2006). High contents of these elements in soil are supposed to increase the risk of the uptake by plants, considering positive correlation between the metal content in soils and vegetables (Naser et al., 2009). Therefore, soil quality standards are important instrument for risk assessment of polluted soils and their impact on human health, water resources and other environmental impacts (Atanassov, 2007). Previous studies have reported variable relationships between the metal concentrations in certain plant parts and their total concentrations in soil. For example, De Pieri et al. (1997) reported inverse relationship between carrot root lead and total soil lead concentrations, and relatively high concentration of cadmium in potato tubers at the site with low cadmium concentration in comparison to other soils studied. According to their findings, the heavy metal concentration in the soil should not be the only criterion for estimating vegetable quality, as processes related to plant metal uptake and translocation must also be taken into account. Considering significant variability among localities concerning the heavy metal concentration in vegetable species surveyed in the present work, beside the analysis of soil quality at small farms, special attention should be paid to genotype specificity of toxic metals accumulation in certain organs.

Considering indisputable correlation between the heavy metal content in foods and aetiology of numerous diseases (WHO 1992; 1995), national and international regulations on food quality have lowered the maximum permissible levels (MPC) of toxic metals in human food (Radwan and Salama, 2006). Various permissible limits for certain metals could be found in the literature. For example, Australian Government prescribed maxi- mum cadmium level in all foods at $0.05 \mathrm{mg}$ $\mathrm{kg}^{-1}$ (Walker, 1988), whereas the Australia New Zealand Food Authority (ANZFA, 1997) tolerates $0.1 \mathrm{mg}$ cadmium $/ \mathrm{kg}$ fresh weight, for root, tuber and leafy vegetables. According to Codex Alimentarius Commission, the permissible limit for lead in cereal and legumes is $0.2 \mathrm{mg} \mathrm{kg}^{-1}$ (CAC 2003).

In the Republic of Serbia, permissible levels of cadmium were set between 0.05 and $0.20 \mathrm{mg} / \mathrm{kg}$, while the permissible limits for lead amount 0.10 or $0.30 \mathrm{mg} / \mathrm{kg}$, in different vegetable species (Official Gazette of Republic of Serbia, 2014). However, MPC for nickel and chromium levels in vegetables have not been defined. The acceptable levels of cadmium and lead are comparable with limits defined by Joint Codex Alimentarius Comission (FAOMHO 2001), which set maximum values in vegetables at $0.2,2.3$ and $0.3 \mu \mathrm{g} / \mathrm{g}$ for cadmium, chromium and lead, respectively. Unlike above cited regulative acts, which prescribe concentration of heavy metals in the vegetable fresh weight, previous Serbian regulative act set allowed levels of lead and cadmium in both fresh and dry vegetables at 1.00 and 3.00 , i.e. 0.05 and $0.30 \mathrm{mg} / \mathrm{kg}$, respectively (Official Gazette of Federal Republic of Yugoslavia, 2002). Cadmium content in edible portions of vegetable species surveyed in this work was above $0.30 \mu \mathrm{g} / \mathrm{g} \mathrm{DM}$ in thirteen samples (Table 3). Vegetables containing above $3.00 \mu \mathrm{g} / \mathrm{g}$ DM of lead comprised $30 \%$ of all analysed samples (Table 3). Chromium contents were above $2.3 \mu \mathrm{g} / \mathrm{g}$ in six samples: potato $(2.54 \mu \mathrm{g} / \mathrm{g})$, cauliflower $(2.69 \mu \mathrm{g} / \mathrm{g})$, parsnip $(4.52 \mu \mathrm{g} / \mathrm{g})$, and spinach $(7.73,7.13$ and $2.81 \mu \mathrm{g} / \mathrm{g})$. The lowest cadmium and lead contamination was recorded in beet root and potato (cadmium: 0.03 and 0.04 $\mu \mathrm{g} / \mathrm{g}$, lead: 0.4 and $0.65 \mu \mathrm{g} / \mathrm{g}$, respectively).

\section{CONCLUSIONS}

The results obtained in present work implicate that contamination of vegetables considerably depends on the point of origin. A large number of samples containing high levels of toxic heavy metals, especially of cadmium and lead, impose the ne- 
cessity for strict regulative guidelines concerning individual vegetable crops production, harvest, handling and storing, in order to diminish the possibility of contamination with respect to the heavy metals. This would increase food quality and safety, and also contribute to preservation of human health.

\section{ACKNOWLEDGEMENTS}

This paper was realized as a part of the project "Continuous monitoring of pollutants in foodstuffs from green markets in Novi Sad" (VI-501-2/2011-49) financed by the City Administration for Environmental Protection, Novi Sad, Republic of Serbia. The results are presented with approval of the City Administration for Environmental Protection, Novi Sad, Republic of Serbia.

\section{REFERENCES}

1. ANZFA (1997). Proposal P144: Review of the maximum permitted concentrations of cadmium in food: executive summary. Full Assessment Report.

2. Atanassov, I. (2007). New Bulgarian soil pollution standards. Bulgarian Journal of Agricultural Science, 14, 68-75.

3. Cempel, M., Nikel, G. (2006). Nickel: a review of its sources and environmental toxicology. Polish Journal of Environmental Studies, 15, 375-382.

4. Codex Alimentarius Commission (CAC) (2003). Evaluation of certain food additives and contaminants. FAO/WHO, Codex stan. 2302001, Rev, 1-2003, Rome.

5. D'Mello, J.P.F. (2003). Food Safety: Contamination and Toxins. Wallingford, Oxon, UK: CABI Publishing.

6. Danilcenko, H.E., Jariene, M., Gajewski, J., Cerniauskiene, J., Kulaitiene, B., Sawicka, P., Aleknaviciene, P. (2011). Accumulation of elements in some organically grown alternative horticultural crops in Lithuania. Acta Scientiarum Polonorum Hortorum Cultus, 10, 23-31.

7. De Pieri, L.A., Buckley, W.T., Kowalenko, C.G. (1997). Cadmium and lead concentrations of commercially grown vegetables and of soils in the Lower Fraser Valley of British Columbia. Canadian Journal of Soil Science, 77, 51-57.

8. Demirezen, D., Aksoy, A. (2006). Heavy metal levels in vegetables in Turkey are within safe limits for $\mathrm{Cu}, \mathrm{Zn}, \mathrm{Ni}$ and exceeded for $\mathrm{Cd}$ and $\mathrm{Pb}$. Journal of Food Quality, 29, 252-265.

9. FAO/WHO (2001). Food additives and contaminants. Joint Codex Alimentarius Commission, FAO/WHO Food standards Programme, ALINORM 01/12A. 2001.
10. Fowler, B.A. (1973), Heavy Metals in the Environment: an Overview. Environmental Health Perspectives, 4, 107-108.

11. Haas, E.M., Levin, B. (2006). Staying Healthy with Nutrition: The Complete Guide to Diet and Nutritional Medicine. Berkeley, California: Celestial Arts, pp. 148-249.

12. He, F.J., MacGregor, G.A. (2001). Fortnightly Review: Beneficial effects of potassium. British Medical Journal, 323, 497-501.

13. Jomová, K., Vollmannová, K., Hegedűsová, A., Morovič, M. (2004). Genotype variability in the relationship to heavy metals intake. Chemické listy, 98, 708.

14. Karavoltsos, S., Sakellari, A., Dimopoulos, M., Dasenakis, M., Scoullos, M. (2002). Cadmium content in foodstuffs from the Greek market. Food Additives and Contaminants, 19, 954-962.

15. Khoshgoftarmanesh, A.H., Aghili, F., Sanaeiostovar, A. (2009). Daily intake of heavy metals and nitrate through greenhouse cucumber and bell pepper consumption and potential health risk for human. International Journal of Food Sciences and Nutrition, 60, 199-208.

16. Kikunaga, S., Miyata, Y., Ishibashi, G., Koyama, F., Tano, K. (1999). The bioavailability of magnesium from Wakame (Undaria pinnatifida) and Hijiki (Hijikia fusiforme) and the effect of alginic acid on magnesium utilization of rats. Plant Foods for Human Nutrition, 53, 265-274.

17. Majid, N.M., Islam, M.M., Enanee, N. (2012). Heavy metal uptake and translocation by semuloH (Fagopyrum dibotrys) from sawdust sludge contaminated soil. Bulgarian Journal of Agricultural Science, 18, 912-923.

18. Mastilović, J. S., Kevrešan, Ž. S., Janić Hajnal, E. P., Novaković, A. R., Radusin, T. I. (2010). Occurrence and risk management of main toxic elements in food production chain. Food and Feed Research, 1, 13-22.

19. Menchaca, I. (2009). Minerals: Elements of Human Nutrition. Teaching Guide. Learning Seed, Chicago, ISBN 1-55740-544-2. http://www.learningseed.com/ guides/1207 Minerals Elements of Human Nutrition Guide.pdf.

20. Naser, M.H., Shil, C.N., Mahmud, U., Rashid, H.M., Hossain, M.K. (2009). Lead, cadmium and nickel contents of vegetables grown in industrially polluted and non-polluted areas of Bangladesh. Bangladesh Journal of Agricultural Research, 34, 545-554.

21. Nicar, M., Pak, C. (1982). Oral magnesium load test for the assessment of intestinal magnesium absorption. Mineral and Electrolyte Metabolism, 8, 44-51.

22. Nielsen, F.H. (2003). Trace elements. In Encyclopedia of Food Sciences and Nutrition. Eds. B. Caballero, L. Trugo, P. Finglas, $2^{\text {nd }}$ edition, Academic Press, London, UK, pp. 5820-5828.

23. Official Gazette of Federal Republic of Yugoslavia, 2002. Regulations for pesticides, metals and metalloids and other toxic substances, 
chemotherapeutics, anabolic steroids and other substances which can be found in food, 32/2002.

24. Official Gazette of Republic of Serbia (2014). Pravilnik o maksimalno dozvoljenim količinama ostataka sredstava za zaštitu bilja u hrani i hrani za životinje i o hrani i hrani za životinje za koju se utvrđuju maksimalno dozvoljene količine ostataka sredstava za zaštitu bilja, 29/14.

25. Parveen, Z., Khuhro, M.I., Rafiq, N. (2003). Market basket survey for lead, cadmium, copper, chromium, nickel and zinc in fruits and vegetables. Bulletin of Environmental Contamination and Toxicology, 71, 1260-1264.

26. Quarterman, J. (1973). Factors which influence the amount and availability of trace elements in human food plants. Qualitas Plantarum, 23, 171-190.

27. Radwan, M.A., Salama, A.K. (2006). Market basket survey for some heavy metals in Egyptian fruits and vegetables. Food and Chemical Toxicology, 44, 1273-1278.

28. Stevanović, D., Jakovljević, M., Pavlović, R. (2001). Heavy metals accumulation in vege- tables in relation to their concentration in the soil. Savremena poljoprivreda, 50, 31-35.

29. Svete, P., Milacic, R., Pihlar, B. (2001). Partitioning of $\mathrm{Zn}, \mathrm{Pb}$ and $\mathrm{Cd}$ in river sediments from a lead and zinc mining area using the BCR three-step sequential extraction procedure. Journal of Environmental Monitoring, 3, 586590.

30. Walker, J.M. (1988). Regulation by other countries in foods and the human environment. National Symposium, Canberra, Australian Government Publishing Service, Proceedings No.2 "Cadmium Accumulation in Australian Agriculture”, pp. 176-185.

31. WHO. (1992). Cadmium. Environmental Health Criteria, Vol. 134, Geneva.

32. WHO. (1995). Lead. Environmental Health Criteria, Vol. 165, Geneva.

33. Zurera, G., Estrada, B., Rincón, F., Pozo, R. (1987). Lead and cadmium contamination levels in edible vegetables. Bulletin of Environmental Contamination and Toxicology, 38, 805812.

\title{
УПОРЕДНА АНАЛИЗА САДРЖАЈА МИНЕРАЛНИХ ЕЛЕМЕНАТА И ТЕШКИХ МЕТАЛА КОД ПОВРТАРСКИХ ВРСТА
}

\author{
Наташа П. Николић, Милан К. Боришев, Слободанка П. Пајевић, Данијела Д. Арсенов, \\ Милан Д. Жупунски \\ Универзитет у Новом Саду, Природно-математички факултет, Департман за биологију и
екологију, Трг Доситеја Обрадовића 2, 21000 Нови Сад, Република Србија
}

Сажетак: Садржај тешких метала (кадмијум, олово, никл и хром) и минералних елемената (фосфрор, калијум, калцијум и магнезијум), у јестивим деловима поврћа (парадајз, кромпир, спанаћ, цвекла, першун, пашканат, шаргарепа, карфиол, паприка и броколи), одређени су методом атомске апсорпционе спектрофотометрије. Узорци су сакупљени са три новосадске зелене пијаце (по 2 узорка са различитих локалитета). Концентрације тешких метала су се кретале у широком распону: од <0,01 до 2,37, <0.01 до 7.72, <0.01 до 5.37 и <0.01 до $9.31 \mu \mathrm{g} / \mathrm{g}$ за кадмијум, хром, никл и олово. Садржај макроелемената у сувој биљној материји се кретао у опадујуђем низу: калијум >калцијум > фоссфор > магнезијум. Највише просечне вредности садржаја тешких метала, као и калијума, калцијума и магнезијума забележене су у спанаћу. Добијени резултати намећу потребу за строгим регулативним смерницама које се односе на производњу повртарских врста, примену агротехничких мера, транспорт до места продаје, као и њихово складиштење, у циљу смањења могућности контаминације поврћа тешким металима.

Кључне речи: контаминација, квалитет хране, минерални елементи, поврће, тешки метали

Received: 4 August 2014

Accepted: 20 October 2014 